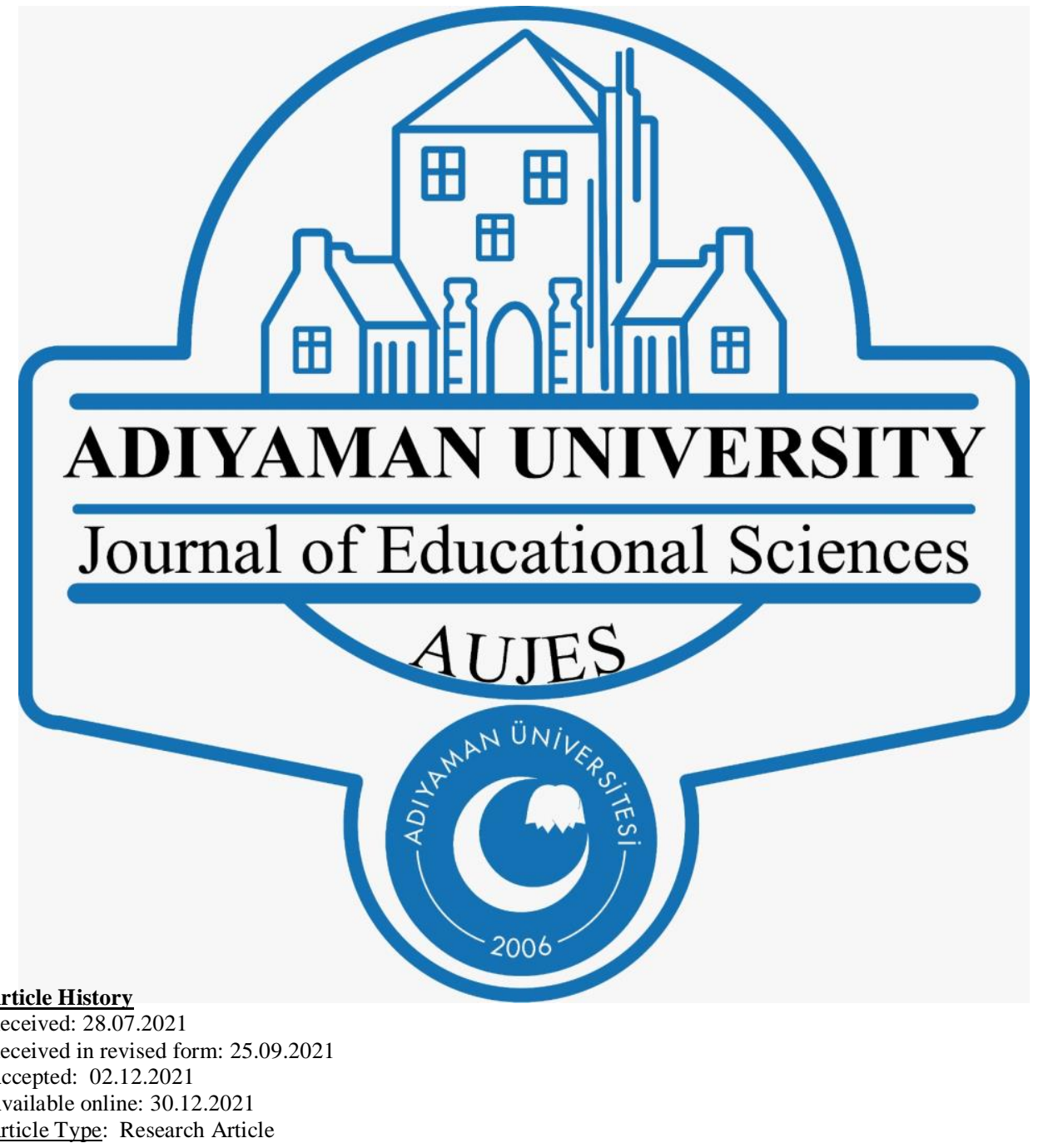

Article Type: Research Article

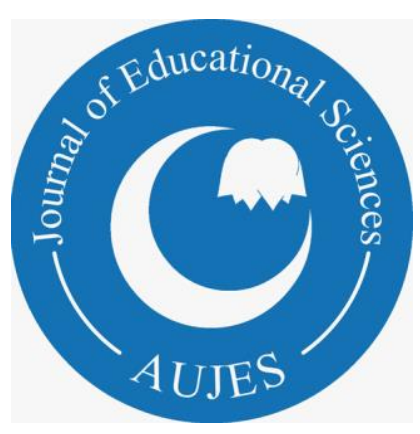

ADIYAMAN UNIVERSITY Journal of Educational Sciences (AUJES) https://dergipark.org.tr/tr/pub/adyuebd

\section{Myths Related to Childhood Sexual Abuse and Gender Equality}

\footnotetext{
Nilüfer KOÇTÜRK ${ }^{1}$, Seval KIZILDAG SAHIN ${ }^{2}$

${ }^{1}$ Hacettepe University, Faculty of Education, Department of Educational Sciences, Ankara, Turkey iD

${ }^{2}$ Adiyaman University, Faculty of Education, Department of Educational Sciences, Adiyaman, Turkey (iD)
}

To cite this article:

Koçtürk, N. \& Kızıldag Sahin, S. (2021). Myths related to childhood sexual abuse and gender equality. Adiyaman Univesity Journal of Educational Sciences, 11(2), 70-79. 


\title{
Myths Related to Childhood Sexual Abuse and Gender Equality
}

\author{
Nilüfer KOÇTÜRK ${ }^{* 1}$, Seval KIZILDAG SAHIN ${ }^{2}$ \\ ${ }^{1}$ Hacettepe University, Faculty of Education, Department of Educational Sciences, Ankara, Turkey \\ ${ }^{2}$ Adiyaman University, Faculty of Education, Department of Educational Sciences, Adiyaman, Turkey
}

\begin{abstract}
Child sexual abuse (CSA) is an important social problem observed in the world in general. This study initially aimed to identify whether the Gender Equality Scale was a valid and reliable measurement device for use in adult individuals. To this aim, validity and reliability studies for the Gender Equality Scale were performed with 353 adults reached though an online survey. The second aim of the study was to seek an answer to the question of whether gender and gender equality variables significantly predict CSA myths. A total of 769 individuals were reached through online surveys to determine predictors of CSA myths. According to the findings, the Gender Equality Scale was determined to be a valid and reliable tool for use with adults. Moreover, the understanding that men are superior and the understanding that women are dependent on men, which are gender variables, explain 38\% of CSA myths, while only the understanding that men are superior significantly predicted CSA myths. Consequently, to reduce the sexism led by the understanding that men are superior, studies can be carried out not only with adults but also with other layers of the society in accordance with the ecological system approach.
\end{abstract}

Key words: Childhood Sexual Abuse, Gender, Gender Inequality, Sexism, Sexual Abuse Myth

\section{Introduction}

Child sexual abuse (CSA) is an important social problem observed in the world in general (Assink et al., 2019; McKibbin \& Humphreys, 2020). This problem may lead to negative medical outcomes like early pregnancy and cause a variety of mental disorders like anxiety, depression, and substance abuse (Brunton \& Dryer, 2020). Further, if victims do not receive the necessary psychosocial interventions, repeated victimization risks increase and the effect of trauma may continue for many years (Brunton \& Dryer, 2020; Koçtürk \& Bilge, 2018; Scoglio et al., 2021). At this point, social support-based interventions offered to abuse victims by parents and society may be an important protective factor preventing occurrence of new abuse cases (Koçtürk \& Bilge, 2018; Scoglio et al., 2021).

Perceived social support from family and society is not just an intervention to be given to victims after CSA but is a factor which will affect the CSA report process (Alaggia et al., 2019; Koçtürk \& Bilge, 2018; Koçtürk \& Bilginer, 2020). Some victims explain the events experienced in an easier way and earlier in situations where they feel they will be believed and not blamed (Koçtürk, 2019). However, when victims making later reports explain events, they are blamed by those around them and may be exposed to other negative attitudes and behavior in society (Koçtürk \& Bilginer, 2020). For example, a study in Turkey found that CSA victims reported late due to a variety of fears like not wanting to cause problems in the family and stigmatization by society; nearly half of victims stated they met negative attitudes from their social surroundings when they reported their abuse (Koçtürk \& Bilginer, 2020). In the literature related to this, it was emphasized that the culture of a society and gender inequality will affect the report process of victims and social support levels displayed towards them (Cromer \& Freyd, 2007; Jones, 2010; Koçtürk \& Bilginer, 2020).

\section{Gender Equality}

Gender equality represents women and men being equally valued without regard to gender and having equal chances and opportunities in access to social, economic, and political resources in life (World Health Organization; WHO, 2008). The common attitudes in society seeing women as not having equal place with men and elevating masculinity are considered to be a violation of human rights (WHO, 2011); this indirectly offers a background where victims are blamed for men engaging in CSA behavior (Cromer \& Freyd, 2007). A sexist belief like "adolescent girls wearing revealing clothing want to be sexually abused" may be given as an example of this situation (Chim et al., 2020). With the emergence and support of sexist statements, CSA myths present

\footnotetext{
* Corresponding Author: Nilüfer KOÇTÜRK, niluferkocturk@hacettepe.edu.tr
} 
among individuals and society are noted in the literature (Brown et al., 2001; Koçtürk \& K1zıldağ, 2018). As is known, myths are unrealistic beliefs about a certain topic, and are mistaken or excessively generalized beliefs preventing the necessary interventions like obstructing the field of child protection and preventing the truth being revealed by denying the existence of abuse (Brown et al., 2001; Ferragut et al., 2020; Sawrikar, 2020). When previous studies are investigated, CSA myths were determined to vary linked to individual factors like gender and educational level (Ferragut et al., 2020). For example, a study in Spain identified that women and individuals with high educational level believed lower rates of CSA myths (Ferragut et al., 2020). At the same time, the research revealed that individuals had more stereotypes about the prevalence of CSA, characteristics of victims, and preventive work such as getting sex education.

As understood from the above explanations and examples, CSA myths are fed by the cultural structure of a society and may be affected by the cultural structure. Sawrikar (2020) reported that individuals in collectivist societies where sexuality is taboo may believe more CSA myths and may blame victims more. Boakye (2009) stated that normalizing or trivializing sexual abuse behaviors may increase the probability of feeding these negative behaviors, noting certain beliefs and perceptions in patriarchal structures, especially, form the basis of some negative behaviors. For example, Chim et al. (2020) identified that there was a high correlation between CSA and being a man. In other words, CSA myths increase by the degree to which sexism is at high levels. In relation to this, Sawrikar (2020) stated that the risk of blaming the victim in collectivist societies emerged due to social norms forbidding discussion of any sexual topic including harassment to protect the purity of women, honor of men and hence family reputation. This situation may prevent dealing with the topic of abuse, including even mentioning it. Therefore, it can be said that CSA myths indirectly tends to maintain and facilitate gender inequality.

Contrary to the importance of CSA myths and sexism mentioned above in the literature, there is no study investigating the CSA myth levels and attitudes toward gender equality of adults in Turkey, displaying different cultural features than Western Society. Further, there are limited studies about CSA myths and the need for new research is emphasized in the literature (Koçtürk \& Kızıldağ, 2018; Koçtürk \& Kızıldağ-Şahin, 2021). From an ecological aspect (Bronfenbrenner, 1979), considering that CSA myths believed by individuals may be affected by cultural factors, assessment of CSA myths in a patriarchal society like Turkey (Erdoğan, 2016; Ozdemir-Sarigil \& Sarigil, 2021) will form the basis of prevention studies. In fact, the importance of the ecologic system approach for prevention of CSA, involving a variety of individual, familial and social risk factors, was mentioned in the literature (Assink et al., 2019; Grauerholz, 2000; Mathews \& Collin-Vézina, 2016). When CSA is dealt with according to the ecologic system approach, many factors like myths present in society (Koçtürk \& Kızıldağ, 2018), legal regulations, gender inequality, and effective operation of child protection systems are factors that affect prevention of CSA and intervention against CSA (Grauerholz, 2000; Koçtürk, 2019). For example, there may be myths in society about divorced parents making unrealistic claims about abuse (Brown et al., 2001). With the presence of these myths, necessary interventions may not be offered considering that the report by the child or parent is unrealistic.

Just as assessment of CSA myths in Turkey will guide prevention studies, it will present information about Turkey to the international literature. In fact, Sawrikar (2020) emphasized that there were more CSA myths in eastern cultures and that there was a need to assess cultures in terms of CSA myths in a study assessing results obtained in South Korea, South Africa, and Switzerland. However, considering abusers know social values and social factors very well, and that they may plan a process of deceiving CSA victims (Craven et al., 2006), it is important to eliminate the lack of knowledge in society and determine needs at the social level in terms of preventing the occurrence of crime. Brown et al. (2001) mentioned the importance of experts providing services related to children and abuse accusations using real scientific information instead of myths. In conclusion, considering that the basic group served by psychological counselors are children and families, there is a requirement to determine needs related to this topic, to see the whole picture in society and to reveal factors predicting CSA myths for effective planning of prevention studies. Moving from this point, the basic aim of this study was to determine whether gender equality and gender predicted CSA myths or not. However, a scale assessing the perspective on gender equality of adults in the context of the "understanding that considers men superior" and the "understanding that sees women as dependent on men" was accessed in the literature (Gender Equality Scale / Toplumsal Cinsiyet Eşitliği Ölçeği; Gözütok et al., 2017; Toraman \& Özen, 2019). It was identified that this scale did not assess the psychometric features of individuals in adulthood. Moving from this point, the research sought answers to the following questions:

a. Is the Gender Equality Scale a valid and reliable scale tool for use with adult individuals?

b. Do the variables of gender and gender equality (understanding that men are superior and understanding that women are dependent on men) significantly predict CSA myths?

\section{Method}




\section{Participants}

A descriptive model was used in this study, in which the validity and reliability studies of the Gender Equality Scale were carried out with adults and the predictors of CSA myths were investigated. This study also used the convenient sampling method ensuring easy access to many people at the same time with economic benefits (Alvi, 2016). This research performed the analyses on two different study groups. Information related to both study groups are presented below.

\section{Study Group I}

Validity and reliability studies for the Gender Equality Scale were performed with 353 adults reached though an online survey. The demographic information for adults is included in Table 1.

Table 1. Demographic information of participants in Study Group I

\begin{tabular}{llll}
\hline Variable & & $f$ & $\%$ \\
\hline Gender & Woman & 290 & 82.2 \\
Marital status & Man & 63 & 17.8 \\
& Married & 330 & 93.5 \\
Number of children & Divorced & 23 & 6.5 \\
& 1 & 145 & 41.1 \\
& 2 & 177 & 50.1 \\
Living place & 3 & 27 & 7.6 \\
& 4 & 3 & .8 \\
Willingness to be educated about sexual abuse & 5 & 1 & .3 \\
& Yes & 2 & .6 \\
& Nillage & 75 & 21.2 \\
& District & 276 & 78.2 \\
\hline
\end{tabular}

$\mathrm{N}=353$

When Table 1 is investigated, most participants were women $(82.2 \%, n=290)$, married $(93.5 \%, n=$ $330)$ and resided in provincial towns $(78.2 \%, n=276)$. Additionally, most participants had a single child $(41.1 \%, n=145)$ or two children $(50.1 \%, n=177)$. Finally, 314 participants $(89 \%)$ were willing to receive education about CSA, while $39(11 \%)$ did not want to receive education about this topic.

\section{Study Group II}

A total of 769 individuals were reached through to determine predictors of CSA myths. Information related to the study group is presented in Table 2.

Table 2. Demographic information of participants in Study Group II

\begin{tabular}{llll}
\hline Variable & & $f$ & $\%$ \\
\hline Gender & Woman & 622 & 80.9 \\
& Man & 147 & 19.1 \\
Marital status & Married & 499 & 64.9 \\
& Divorced & 70 & 9.1 \\
& Single & 200 & 26.0 \\
Living place & Village & 14 & 1.8 \\
& District & 163 & 21.2 \\
& Province & 592 & 77.0 \\
Level of education & Undergraduate education & 646 & 84 \\
& Under undergraduate education & 123 & 16 \\
Training status on CAN & Yes & 169 & 22 \\
Institutions or resources trained for CAN & No & 600 & 78 \\
& Ministry of Education & 74 & 9.6 \\
& University & 36 & 4.7
\end{tabular}


Policies

Note. $\mathrm{N}=769 ; \mathrm{CAN}=$ Child abuse and neglect.

As can be seen from Table 2, most adults participating in this research were women $(80.9 \%, n=622)$, married $(64.9 \%, n=499)$ and resided in provincial towns $(77 \%, n=592)$. The majority of participants had education up to undergraduate level $(84 \%, n=646)$. At the same time, $78 \%$ of participants $(n=600)$ had not received education about CSA, while participants receiving education had mainly received this from the Ministry of National Education $(9.6 \%, n=74)$. With this information, the average age of the participants is $37.11(\mathrm{sd}=10.04)$.

\section{Data collection tools}

\section{Personal Information Form}

This form was prepared by the researchers in order to collect information about the gender, marital status, number of children, place of residence, educational level, desire to receive education about CSA, organization where CSA education was received and resources of participants.

\section{Gender Equality Scale}

This scale was developed by Gözütok et al. (2017) to determine the opinions of high school students' gender equality. The scale comprises 13 items with two subdimensions of "understanding that men are superior" and "understanding that women are dependent". The 5-point Likert rating (definitely disagree, disagree, partly agree, agree and definitely agree) scale does not give total points and does not contain items with inverse points. The subdimension point interval for "understanding that men are superior" is $8-40$, while the subdimension point interval for "understanding that women are dependent on men" is 5-25. High points obtained from the understanding that men are superior subdimension means acceptance of men being superior to women and male dominance; high points obtained for the understanding that women are dependent on men subdimension means opinions related to women being dependent on men in family relationships and women requiring permission from men to act (Gözütok et al., 2017). Reliability studies for the form of the scale developed for high school students found internal consistency coefficient of .88 for the first subdimension and .70 for the second subdimension. Confirmatory factor analysis studies performed within the scope of validity studies observed the scale had significant and perfect level for fit index values $\left(X^{2}=97.01\right.$, sd $=53, p=.00$, $X^{2} / 206=1.83 ; \mathrm{RMSEA}=.084, \mathrm{SRMR}=.07, \mathrm{RMR}=.06, \mathrm{NFI}=.91, \mathrm{NNFI}=.94, \mathrm{CFI}=.99, \mathrm{IFI}=.99, \mathrm{AGFI}=$ .92; Gözütok et al., 2017). Within the scope of this study, the internal consistency coefficient for the understanding of male superiority subdimension was .86 , while the internal consistency coefficient for the understanding of women's dependence on men subdimension was .77.

\section{Childhood Sexual Abuse Myths Scale (CSAMS)}

The scale was developed by Koçtürk and Kızıldağ (2018) with the aim of measuring CSA myths among university students. Later, validity and reliability studies for adult individuals were performed by Koçtürk and K1zıldağ-Şahin (2021). Both forms of the scale contain 22 items and two factors of "reports and reliability" and "abuser features". The 5-point Likert scale $(1=$ completely disagree, $2=$ disagree, $3=$ undecided, $4=$ partly agree and $5=$ completely agree) has total points and the points interval varies from 22 to 110 . High points obtained from the scale indicates that university students believe high levels of CSA myths. Within the scope of reliability studies for the scale, the internal consistency coefficients, and test-retest reliability was investigated. The internal consistency coefficients for the dimensions were .84 and .85 , with value of .90 for the whole scale. For test-retest reliability, the corrected correlation coefficients were .93 for the report and reliability dimension and .89 for the abuser features dimension. Confirmatory factor analysis results within the scope of validity studies for university students observed the scale had significant and acceptable values for fit indices $\left(X^{2}=\right.$ 511.73, $\mathrm{sd}=206, p=.00, X^{2} / 206=2.484 ;$ RMSEA $=.084$, SRMR $=.07, \mathrm{RMR}=.06, \mathrm{NFI}=.91, \mathrm{NNFI}=.94$, $\mathrm{CFI}=.95, \mathrm{IFI}=.95, \mathrm{RFI}=.90, \mathrm{AGFI}=.80, \mathrm{GFI}=.84$; Koçtürk \& Kızıldağ-Şahin, 2018). At the same time, confirmatory factor analysis results were performed in validity studies for adults $\left(X_{419}^{2}=851,767, p=.00\right.$, Normed $x^{2}=4.22 ; \mathrm{CFI}=.93 ; \mathrm{NFI}=.92 ; \mathrm{RFI}=.90 ; \mathrm{IFI}=.93 ; \mathrm{TLI}=.92 ; \mathrm{RMSEA}=.08 \mathrm{SRMR}=.04 ;$ Koçtürk $\&$ Kızıldağ-Şahin, 2021). It was seen that these values are at an acceptable level. Within the scope of reliability studies for the adult form, the internal consistency coefficient for the whole scale was .97. Within the scope of this study, the internal consistency coefficient for the whole scale was identified as .94.

\section{Analysis of Data and Procedure}

For implementation of this research, necessary permissions were obtained from the Non-Interventional Clinical Research Ethics Committee of the university where one of the researcher's is employed. After ethics committee 
permission, data collection tools were uploaded to "Google Forms" and then the study was announced by the researchers in the online environment. Before seeing the scales, the participants were informed about the research with the online form and their consent was obtained online. Participants who consented to participate in the study were able to see the scales.

This study firstly performed confirmatory factor analysis for 353 adults included in Study Group I. Before confirmatory factor analysis can be performed within the scope of validity studies, measurements must be reviewed for normality, multiple collinearities, outlier values and missing data (Kline, 2010). Analysis is begun after ensuring that the data meet these assumptions. At the same time, internal consistency coefficients were investigated for reliability of the scales. As measurements used online surveys where answers were provided one-by-one without progression unless answered, there was no missing data. Additionally, the skewness and kurtosis values for item points were assessed with a linearity scatter plot for the normality assumption. Outlier values were investigated with the Mahalanobis distance test for outlier values of linear components. As a result of investigations, data met the assumptions for analysis. Analysis of data used the AMOS 26 and SPSS 26 programs. The error share in the research was taken as .05 .

At the same time, this research performed regression analysis on data obtained with online surveys of 769 adults in Study Group II. Participants in the research were presented with an informed consent form and data from all participants who accepted participation in the study were analyzed. Analysis of data used SPSS 26. In this stage, tests were performed to see whether statistical assumptions for regression analysis were met or not. The data in the research were investigated with skewness and kurtosis values for fit to normal distribution and all variables included in the analysis were observed to have values between 1.35 and -.60. As the investigated skewness and kurtosis coefficients were in the interval between -2 and +2 (Tabachnick \& Fidell, 2007), the data was shown to have normal distribution. Within the scope of preliminary analyses performed for data analysis, normality, linearity, multiple collinearity and equivalent variance assumptions were tested. The Durbin-Watson value was investigated for autocorrelation between variables (maximum value $.33,<4$ ), so it was concluded there was no autocorrelation between variables (Yavuz, 2009). At the same time, tolerance, and variance inflation values (maximum $=1.79,<5$ ) were examined and the assumptions for variance analysis were investigated. Also, the gender variable was assigned as a dummy variable in the regression analysis.

\section{Findings}

The findings of the study are presented under two headings according to the sub-problems of the study.

\section{a. Validity and Reliability Study for Gender Equality Scale}

\section{Confirmatory Factor Analysis Findings}

Confirmatory factor analysis and validity analysis were investigated to apply the Gender Equality Scale to adults. Results related to the analyses are given in Figure 1.

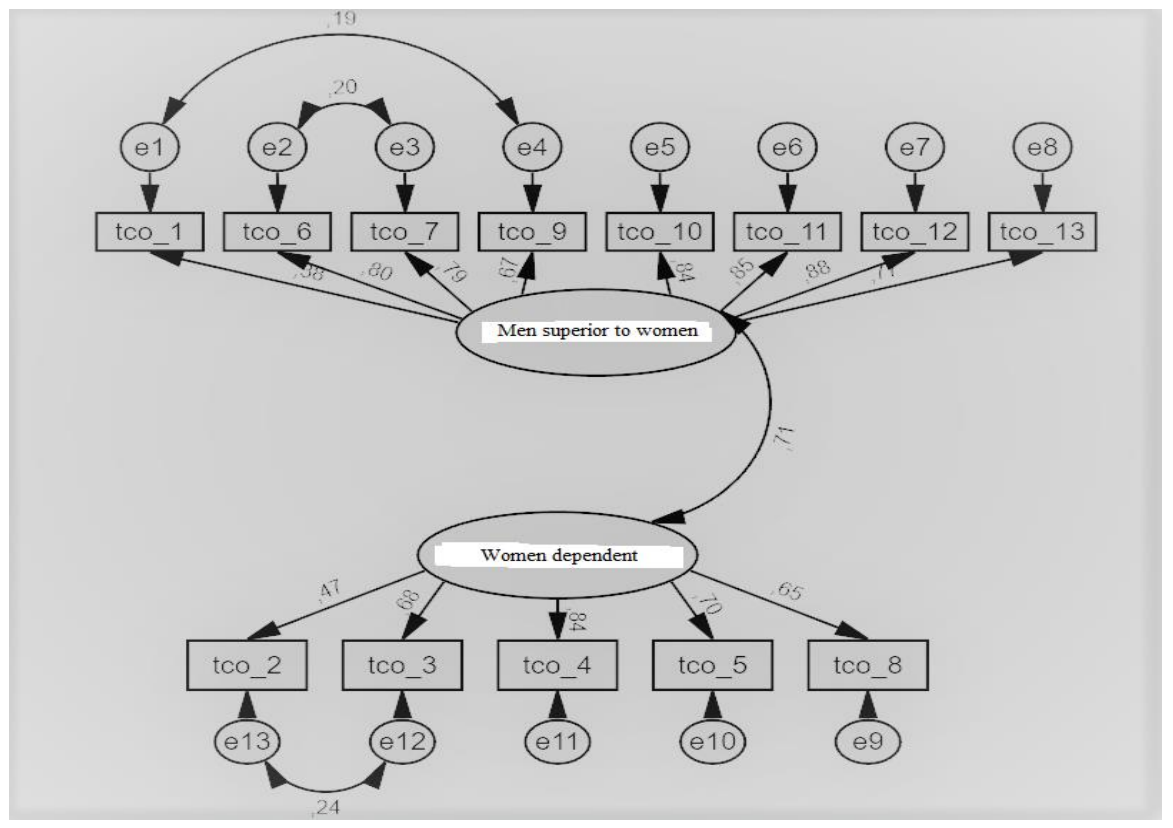

Figure 1. SGES confirmatory factor analysis results 
As seen on Figure 1, the standardized regression coefficients for scale items were .39-.87 for the understanding that men are superior, and .51-.83 for the understanding that women are dependent on men. The average variance explained (AVE) by the understanding that men are superior dimension is .58, while the AVE for the understanding that women are dependent is .46. Kline (2010) states that AVE values with weights of .50 and above have large effects. The AVE and CR values are shown. According to Hair et al. (2009), the construct reliability (CR) should be larger than .7. Accordingly, the items included on both dimensions of the scale indicate that the dimensions are valid. At the same time, the CR values related to the dimensions were .92 for the 'men are superior' dimension and .81 for 'women are dependent' dimension. Thus, these values show the scale meets the similitude validity condition. In conclusion, the general fit coefficients for the model show the hypothesis model has acceptable levels of fit $\left({ }_{53} \mathrm{X}_{353}^{2}=245.008 p=.00\right.$, Normed $x^{2}=4.01$; CFI $=.93$; NFI $=$ $.91 ; \mathrm{RFI}=.86 ; \mathrm{IFI}=.93 ; \mathrm{TLI}=.91 ; \mathrm{RMSEA}=.08 ; \mathrm{SRMR}=.08)$. Acceptable goodness of fit is shown if the $\mathrm{X}^{2}$ / df value is 3 or smaller (Kline, 2011); if RMSEA and SRMR values are below .08 (Byrne, 2010); and if IFI and CFI are .90 and above (Bentler, 1990). For this reason, these values prove the coefficients related to the model are adequate.

\section{Reliability Study}

As a result of the reliability study for the scale, the item-total correlation coefficients for the 'understanding that men are superior dimension' were $.37-.80$, with internal consistency coefficient of .89. For the 'understanding that women are dependent on men dimension' of the scale, the item-total correlation coefficients were $.50-.69$, with internal consistency coefficient of .79. The internal consistency coefficient for the whole scale (stratified alpha) was found to be .90 .

\section{b. Prediction of Childhood Sexual Abuse Myths}

Table 3 presents the correlation values for dependent and independent variables. Accordingly, for CSA myths, there was a positive correlation with understanding that men are superior $(\mathrm{r}=.62, p=.001)$; a positive correlation with understanding that women are dependent $(\mathrm{r}=.43, p=.001)$; and a positive correlation with gender $(\mathrm{r}=.15, p=.001)$. For the understanding that men are superior, there was a positive correlation with the understanding that women are dependent $(\mathrm{r}=.66, p=.001)$ and with gender $(\mathrm{r}=.25, p=.001)$. Finally, for the understanding that women are dependent to men, there was a positive correlation with gender $(\mathrm{r}=.23, p=.001)$. The value of this correlation (from .15 to .66) appeared to be at low levels (0.30-0.00 low, 0.70-0.30 moderate and 0.70-1.00 high; Büyüköztürk, 2007). Additionally, the regression analysis for correlations between variables can be said to have acceptable values.

Table 3. Pearson correlation coefficients for dependent and independent variables

\begin{tabular}{|c|c|c|c|c|c|c|}
\hline Variable & 1 & 2 & 3 & 4 & $\overline{\mathrm{X}}$ & SD \\
\hline 1. Childhood sexual abuse myths & 1 & & & & 27.95 & 7.68 \\
\hline $\begin{array}{l}\text { 2. Understanding that considers men superior } \\
\text { to women }\end{array}$ & $.617^{* *}$ & 1 & & & 10.30 & 3.11 \\
\hline $\begin{array}{l}\text { 3. Understanding that considers women } \\
\text { dependent }\end{array}$ & $.431^{* *}$ & $.655^{* *}$ & 1 & & 8.30 & 2.88 \\
\hline 4. Gender & $.149^{* *}$ & $.252^{* *}$ & $.227^{* *}$ & 1 & 1.19 & .39 \\
\hline
\end{tabular}

Note. $* * p=.001$

Table 4. Findings concerning the prediction of childhood sexual abuse myths

\begin{tabular}{|c|c|c|c|c|c|c|}
\hline Predictive variables & $\mathrm{R}$ & $\mathrm{R}^{2}$ & $\Delta \mathrm{R} 2$ & $\beta$ & $t$ & $\mathrm{~F}$ \\
\hline Constant & .62 & .38 & .38 & & $13.24 *$ & 157.40 \\
\hline Understanding that considers men superior to women & & & & .59 & $15.45^{*}$ & \\
\hline Understanding that considers women dependent & & & & .05 & 1.29 & \\
\hline Gender & & & & -.01 & -.34 & \\
\hline
\end{tabular}

Note. ${ }^{*} p<.05$

As seen from Table 4, the variables ofunderstanding that men are superior explained $38 \%$ of the CSA myths. The results of the analysis identified that the understanding that men are superior significantly predicted 
CSA myths, while the understanding that women are dependent on men and the gender variable were not identified to significantly predict CSA myths.

\section{Results and Discussion}

In this study which performed validity and reliability studies for the Gender Equality Scale used for adults and investigated predictors of CSA myths, firstly the Gender Equality Scale was determined to be a valid and reliable tool for use with adults. As is known, confirmatory factor analysis studies include a variety of statistical values indicating the fit of the model to data, with values like RMSEA, CFI, NNFI and GFI generally noted in the assessment of data fit to the model (Kline, 2010). This study obtained values of chi square $353=245.008, p=$ $.00 ;$ Normed $x^{2}=4.01 ; \mathrm{CFI}=.93 ; \mathrm{NFI}=.91 ; \mathrm{RFI}=.86 ; \mathrm{IFI}=.93 ; \mathrm{TLI}=.91 ; \mathrm{RMSEA}=.08$ and $\mathrm{SRMR}=.08$ as a result of testing the two-factor model of the scale structure. For this reason, these values count as evidence that the coefficients related to the model are adequate and show the scale structure was confirmed (Kline, 2010). Additionally, analysis results show the 13 items included on the scale have construct validity in the adult sample, similar to the adolescent sample (Gözütok et al., 2017). Hence, all items on the scale were within acceptable limits for the subscales. The items had $t$ values from .15 to .77 and the multiple correlation square values varied from .38 to .88 and all values were significant. Additionally, it is expected in the literature that the calculated internal consistency value will be .70 and above for a scale to be accepted as having high levels of reliability (Tavşanc1l, 2002). The internal consistency coefficient for the reliability coefficients for the 13 items on the scale was .90 for the whole scale, indicating the scale met this criterion.

Another important contribution of this study to the literature is the investigation of gender equality as predictors of CSA myths. According to findings, the variables of gender, the understanding that men are superior and the understanding that women are dependent on men explain 38\% of the CSA myths, while only the understanding that men are superior significantly predicted CSA myths. Some studies in the literature stated that men believe more CSA myths (DiDonato, 2017), while some studies stated that there is no difference between genders according to the features of CSA myths and education level of participants (Ferragut et al., 2020). Considering the majority of participants included in this study were women and that male participants had high educational levels, the reason for the lack of difference between genders may be due to the sociocultural features of the sample. In other words, the reason for the differences in findings between studies in the literature may be caused by differences linked to confounding/mediating effects of educational level. In fact, in the literature is it known that men believe more CSA myths and CSA myths reduce as educational level increases (e.g., DiDonato, 2017). However, Cengiz (2020) emphasized there was a correlation between narcissism levels in adults and sexist attitudes. Narcissism and similar personality traits may cause inconsistency between results, like educational level. However, in order to make more accurate interpretations about this topic, studies investigating the mediating role of factors like education, etc. according to type of CSA myths (toward the victim, abuser, specific to the event) in the relationship between gender and CSA myths should be performed.

In this study, the understanding that men are superior was identified to significantly predict CSA myths, while the understanding that women are dependent on men was not identified to be a predictor. As is known, sexism may be seen in two basic forms of hostile and protective sexism (Cengiz, 2020; Glick \& Fiske, 2001). While the understanding that men are superior may be the most obvious and visible face of sexism, society may be inured to protective sexism with cultural values in Turkish society and the understanding that women are dependent on men may be more normalized culturally. For this reason, though adults may believe CSA myths at low levels, they may see women as dependent on men. In fact, studies completed in Turkey state that women adopt protective sexism like men (Cengiz, 2020) and women have a role in maintaining gender roles and preventing equality (e.g., Özkan, 2014). Another reason for the lack of prediction of CSA myths by the understanding that women are dependent on men may be related to the perception of a range of legal implementations about female-male equality in Turkey and the place of women in society. As is known, Turkey is 130 out of 153 countries in terms of gender equality (World Economic Forum, 2020). Participants may see women in society as in a position that is dependent on men due to their own experiences and the present conditions. In fact, the literature states that women remain in the background compared to men in many areas like domestically, in the career world and media, and positive discrimination in these areas was mentioned to ensure equality (Dedeoğlu, 2009; Demirdirek \& Şener, 2014; Kavas, 2018). Further, even women with high educational level are known to be exposed to gender inequality in Turkey (Halifeoğlu, 2020; Suğur \& Cangöz, 2016). In this study, considering the majority of participants were women with high educational level, the presence of the understanding that women are dependent on men within this group may be an indicator of how important studies on this topic are in terms of sustaining gender inequality. However, as this research was a descriptive study, causative studies may be completed about the understanding that women are dependent on men to make a clearer interpretation. 
This study has some limitations. First, the study is cross-sectional. Secondly, data were collected online which may be considered another limitation of the study. While online collection of data ensures many people displaying different cultural characteristics are reached, it prevents access to adults without mobile telephones or internet access. Additionally, since the majority of the research participants are women, university educated, living in the province and married, the results can be evaluated in the context of these participant characteristics. Finally, the study did not make a detailed definition about CSA types and subjective assessment of CSA by participants may be considered a limitation of the study (Ferragut et al., 2020).

\section{Conclusion and Recommendations}

Along with the limitations mentioned above, this study includes participants from many locations in Turkey and provides a variety of contributions to the literature with this broad sample. Based on the findings obtained in the study, educational studies may be completed for adults with the understanding that men are superior. Contrary to this, in light of information in the literature, it may be assumed that these adults may ignore possible CSA situations, may not receive support from the relevant areas and may blame the victim. Additionally, studies may be completed in accordance with the ecologic system approach (Bronfenbrenner, 1979; Grauerholz, 2000) with other layers in society, not just adults, in order to reduce sexism led by the understanding that men are superior. The media may be an important factor in the formation and continuation of CSA myths (Popović, 2017) and considering the power of the media should not be underestimated in gender inequality or roles (Doğan, 2020; Karanfil, 2019), organizations related to the media may be used to inform the public. Additionally, organizations and studies about the media may be given weight in reducing these interrelated problems. Also, data obtained in new studies completed with individuals from different cultural backgrounds may test the validity for these groups. Finally, considering its relationship with sexism and CSA myths, trainings that reduce sexism and myths can be provided in groups serving CSA victims, and gender equality issues can be added to the program in parent trainings.

\section{References}

Alaggia, R., Collin-Vézina, D., \& Lateef, R. (2019). Facilitators and barriers to child sexual abuse (CSA) disclosures: A research update (2000-2016). Trauma, Violence, \& Abuse, 20(2), 260-283.

Alvi, M. (2016). A manual for selecting sampling techniques in research. https://mpra.ub.unimuenchen.de/70218/

Assink, M., van der Put, C. E., Meeuwsen, M. W., de Jong, N. M., Oort, F. J., Stams, G. J. J., \& Hoeve, M. (2019). Risk factors for child sexual abuse victimization: A meta-analytic review. Psychological Bulletin, 145(5), 459-489. https://doi.org/10.1037/bul0000188

Boakye, K. E. (2009). Culture and nondisclosure of child sexual abuse in Ghana: A theoretical and empirical exploration. Law \& Social Inquiry, 34(4), 951-979. https://doi.org/10.1111/j.1747-4469.2009.01170.x

Bronfenbrenner, U. (1979). The ecology of human development: Experiments by nature and design. Harvard University Press.

Brown, T., Frederico, M., Hewitt, L., \& Sheehan, R. (2001). The child abuse and divorce myth. Child Abuse Review: Journal of the British Association for the Study and Prevention of Child Abuse and Neglect, 10(2), 113-124. https://doi.org/10.1002/car.671

Brunton, R., \& Dryer, R. (2020). Child sexual abuse and pregnancy: A systematic review of the literature. Child Abuse \& Neglect, 104802. https://doi.org/10.1016/j.chiabu.2020.104802

Cengiz, A. A. (2020). Narsisizm ve çelişik duygulu cinsiyetçilik: Cinsiyet bağlamında bir inceleme. Pamukkale Üniversitesi Sosyal Bilimler Enstitüsü Dergisi, 41, 39-73. https://doi.org/10.30794/pausbed.683620

Chim, I., MagalhÃes, E., Graça, J., Antunes, C., \& Ferreira, C. (2020). Child sexual abuse myth scale: validity and reliability evidence in the Portuguese context. Journal of Child Sexual Abuse, 29(7), 802-820. https://doi.org/10.1080/10538712.2020.1801934

Craven, S., Brown, S., \& Gilchrist, E. (2006). Sexual grooming of children: Review of literature and theoretical considerations. Journal of Sexual Aggression, 12(3), 287-299.

Cromer, L. D., \& Freyd, J. J. (2007). What influences believing child sexual abuse disclosures? The roles of depicted memory persistence, participant gender, trauma history, and sexism. Psychology of Women Quarterly, 31(1), 13-22. https://doi.org/10.1111/j.1471-6402.2007.00327.x 
Dedeoğlu, S. (2009). Eşitlik mi ayrımcılık mı? Türkiye'de sosyal devlet, cinsiyet eşitliği politikaları ve kadın istihdamı. Çalışma ve Toplum, 2(21), 41-54.

Demirdirek, H., \& Şener, Ü. (2014). 81 il için toplumsal cinsiyet eşitliği karnesi 2014. https://dspace.ceid.org.tr/xmlui/handle/1/926

DiDonato, S. (2017). Comparing Medical Students' Adherence to Child Sexual Abuse Myths in South Africa and the United States of America (Doctoral dissertation, The Chicago School of Professional Psychology).

Doğan, M. D. (2020). "Medya ve toplumsal cinsiyet üzerine tartışmalar” kitabı. Medya ve Kültürel Çalışmalar Dergisi, 2(2), 53-57.

Dünya Ekonomik Forumu. (2020). The Global Gender Gap Report 2020. https://www.weforum.org/reports/gender-gap-2020-report-100-years-pay-equality

Ercan, İ., \& Kan, E. (2004). Ölçeklerde güvenirlik ve geçerlik. Uludağ Üniversitesi Tıp Fakültesi Dergisi, 30(3), 211-216.

Erdogan, E. (2016). 'I pray for the factory to continue earning money': The familial factory regime of the 'Sun'food factory in Turkey. Feminist review, 113(1), 68-84. https://doi.org/10.1057/fr.2016.8

Ferragut, M., Rueda, P., Cerezo, M. V., \& Ortiz-Tallo, M. (2020). What do we know about child sexual abuse? Myths and truths in Spain. Journal of Interpersonal Violence. https://doi.org/10.1177/0886260520918579

Glick, P., \& Fiske, S. T. (2001). An ambivalent alliance: Hostile and benevolent sexism as complementary justifications for gender inequality. American Psychologist, 56(2), 109-118.

Gözütok, F. D., Toraman, Ç., \& Acar-Erdol, T. (2017). Toplumsal cinsiyet eşitliği ölçeğinin (TCEÖ) geliştirilmesi. Elementary Education $\quad$ Online, 16(3), 1036-1048. https://doi.org/10.17051/ilkonline.2017.330240

Grauerholz, L. (2000). An ecological approach to understanding sexual revictimization: Linking personal, interpersonal, and sociocultural factors and processes. Child Maltreatment, 5(1), 5-17. https://doi.org/10.1177/1077559500005001002

Halifeoğlu, M. (2020). Akademinin habitusu ve toplumsal cinsiyeti: Kadın akademisyenler. Uluslararası Medeniyet Çalışmaları Dergisi, 5(2), 167-181.

Jones, A. (2010). Patriarchy, gender inequality and culture: Colliding dynamics in the construction of child sexual abuse in the Caribbean.http://eprints.hud.ac.uk/id/eprint/9573/1/Patriarchy_C ulture_and_Gender_Inequality_-_Stop_it_Now_Aug_2010.pdf

Karanfil, T. (2019). Cinsiyet eşitliği ve medya. Journal of Awareness, 4(3), 281-292.

Kavas, A. (2018). Karşılaştırmalarla 81 il için toplumsal cinsiyet eşitliği karnesi-2018. https://dspace.ceid.org.tr/xmlui/handle/1/927

Kline, R. B. (2010). Principles and practice of structural equation modeling: Methodology in the social sciences (3rd edition). The Guilford Press.

Kline, R.B. (2011). Principles and practice of structural equation modeling. The Guilford Press.

Koçtürk, N. (2019). Çocuk ihmali ve istismarı. Ed. N. Ş. Özabacı, Çocuk ruh să̆lı̆̆ı ve psikolojisi içinde (s. 236-263). Nobel Akademik Yayınc1lık.

Koçtürk, N., \& Bilge, F. (2018). Social support of adolescent survivors of child sexual abuse and sexual revictimization in Turkey. Journal of Child Sexual Abuse,27(1), 38-52. https://doi.org/10.1080/10538712.2017.1354348

Koçtürk, N., \& Bilginer, S. Ç. (2020). Adolescent sexual abuse victims' levels of perceived social support and delayed disclosure. Children and Youth Services Review, 118, 105363. https://doi.org/10.1016/j.childyouth.2020.105363 
Koçtürk, N., \& Kızıldağ, S. (2018). Çocukluk Dönemi Cinsel İstismarına İlişkin Mitler Ölçeği’nin geliştirilmesi: Geçerlik ve güvenirlik çalışması. Adıyaman Üniversitesi Sosyal Bilimler Enstitüsü Dergisi, (30), 778-808.

Koçtürk, N., \& Kızıldağ-Şahin, S. (2021). Çocukluk Dönemi Cinsel İstismarına İlişkin Mitler Ölçeği Ebeveyn Formu: Geçerlik ve Güvenirlik Çalışması. Turkish Journal of Child and Adolescent Mental Health, 28(1), 31-38.

Mathews, B., \& Collin-Vézina, D. (2016). Child sexual abuse: Raising awareness and empathy is essential to promote new public health responses. Journal of Public Health Policy, 37(3), 304-314.

McKibbin, G., \& Humphreys, C. (2020). Future directions in child sexual abuse prevention: An Australian perspective. Child Abuse \& Neglect, 104422. https://doi.org/10.1016/j.chiabu.2020.104422

Ozdemir-Sarigil, B., \& Sarigil, Z. (2021). Who is patriarchal? The correlates of patriarchy in Turkey. South European Society and Politics, 1-27.

Özkan, K. (2014). Kadınların kolektif eylem yöneliminin yordayıcıları: Kültürel benlik kurguları, kadın kimliğ ile özdeşleşme, kadınların sosyal baskınlık yönelimi ve sistemi meşrulaştırma eğilimi (Master's thesis, Uludağ Üniversitesi).

Popović, S. (2017). Media role in supporting child sexual abuse myths and stereotypes: Content analysis of online CSA news and comments. Child maltreatment \& well-being: Contemporary issues, research \& practice (Book of abstracts), 62-63.

Sawrikar, P. (2020). Service providers' understanding of cross-cultural differences in belief of myths about child sexual abuse: Results from a program evaluation study in Australia. Children and Youth Services Review, 118, 105391. https://doi.org/10.1016/j.childyouth.2020.105391

Scoglio, A. A., Kraus, S. W., Saczynski, J., Jooma, S., \& Molnar, B. E. (2021). Systematic review of risk and protective factors for revictimization after child sexual abuse. Trauma, Violence ve Abuse, 22(1), 41-53. https://doi.org/10.1177/1524838018823274

Suğur, S., \& Cangöz, İ. (2016). Üniversite Yönetiminde Kadınların Eksik Temsili Üzerinde Toplumsal Cinsiyet İlişkilerinin Rolü. Amme İdaresi Dergisi, 49(3), 89-115.

Tavşancıl, E. (2002). Tutumların ölçülmesi ve SPSS ile veri analizi. Nobel Akademik Yayıncılık.

Toraman, C., \& Özen, F. (2019). An investigation of the effectiveness of the gender equality course with a specific focus on Faculties of Education. Educational Policy Analysis and Strategic Research, 14(2), 628 .

World Health Organisation (WHO, 2008). Women and gender equity. https://www.who.int/social_determinants/publications/womenandgender/en/

Yavuz, S. (2009). Hataları ardışık bağımlı (otokorelasyonlu) olan regresyon modellerinin tahmin edilmesi. Atatürk Üniversitesi İktisadi ve İdari Bilimler Dergisi, 23 (3), 123-140. 